\title{
Analisis Struktural Pisa'an Pemberian Adok Pada Pernikahan Adat Komering di Desa Kurungan Nyawa
}

\author{
Neti Kartini ${ }^{1 *}$ \\ Suryani ${ }^{2 *}$ \\ ${ }^{1}$ Alumni Program Studi Pendidikan Bahasa dan Sastra Indonesia STKIP Nurul Huda \\ 2 Dosen Program Studi Pendidikan Bahasa dan Sastra Indonesia STKIP Nurul Huda \\ *E-mail: alnetikartini@gmail.com
}

\begin{abstract}
Abstrak
Penelitian ini bertujuan mendeskripsikan struktur yang terkandung dalam Pisa'an pemberian Adok pada pernikahan adat Komering di desa Kurungan Nyawa. Penelitian ini dilatar belakangi oleh isi Pisa'an pada pemberian adok pernikahan adat Komering yang kaya akan pengalaman, petuah, nasehat dan cerminan kebudayaan masyarakat Komering. Teori struktural yang digunakan adalah teori Ade, dkk. Metode dalam penelitian ini adalah deskriptif analitatif. Teknik pengumpulan data melalui proses perekaman, observasi dan wawancara. Penelitian ini menganalisis secara menyeluruh unsur fisik yaitu diksi, imaji, kata konkret, majas, verifikasi, dan tifografi. Serta unsur batin yaitu tema, nada dan suasana, perasaan, dan amanat dari sebuah Pisa'an serta kaitan setiap unsur Pisa'an yang ada di desa Kurungan Nyawa. Hasil dari penelitian ini menunjukkan bahwa setiap unsur Pisa'an pemberian Adok pada pernikahan adat Komering mewakili setiap cerita tentang kedua pengantin yang diberikan Adok baik itu tentang kisah cintanya, tentang kepribadiannya, tentang latar belakang keluarganya, dan petuah-petuah untuk menjalani kehidupan berumah tangga. Pisa'an Komering yang satu ini unik dan memiliki ciri khas sendiri yang membedakannya dari pantun-pantun lainya. Pisa'an sarat akan kebudayaan masyarakat Komering yang turun temurun, makna yang mengandung petuahpetuah dalam mengarungi kehidupan berumah tangga dan kisah cinta yang terjadi pada kedua pengantin.
\end{abstract}

Kata kunci: Pisa’an, Pernikahan, Komering, Struktural, Unsur Fisik, Unsur Batin, Kurungan Nyawa.

\section{PENDAHULUAN}

Latar belakang penelitian ini ada tiga yang paling mendasar yaitu pertama, Pisa'an merupakan identitas masyarakat Komering, yang lahir dan diturunkan dari generasi ke generasi melalui lisan dan mengalami berkembang seiring dengan berkembangnya peradaban masyarakat suku Komering. Perkembangan peradaban masyarakat Komering itu secara jelas tergambar di dalam isi Pisa'an. Isi Pisa'an mengandung pengalaman, petuah, nasehat, serta cerminan kebudayaan suku Komering yang kuat. Kedua, karena eksistensi Pisa'an di desa Kurungan Nyawa berdasarkan fakta dilapangan menunjukkan mengalami gejala kepunahan, penurunan, dan perkembangannya sedikit terhambat padahal Kurungan Nyawa merupakan tempat tumbuh dan berkembangnya Pisa'an dari zaman ke zaman, maka perlu adanya upaya pencegahan kepunahan terhadap eksistensi Pisa'an dalam masyarakat desa Kurungan Nyawa melalui pendokumentasian serta pengkajian terhadap Pisa'an. Ketiga, penelitian ini juga diperkuat oleh visi misi prodi Pendidikan Bahasa dan Sastra Indonesia, point ketiga tentang pelestarian kearifan lokal terutama milik masyarakat pribumi yang dapat berupa kebiasaan, adat istiadat, budaya dan sastra.

Rumusan masalah berdasarkan latar belakang diatas adalah bagaimanakah struktur Pisa'an pemberian Adok pada pernikahan adat Komering di desa Kurungan Nyawa ?, sedangkan tujuan dari penelitian ini adalah mendeskripsikan struktur yang terkandung dalam Pisa'an pemberian Adok pada pernikahan adat Komering di desa Kurungan Nyawa. Manfaat dari penelitian ini,secara Teoritis yaitu dapat dijadikan acuan untuk penelitian selanjutnya berkaitan dengan sastra Komering terutama Pisa'an. sedangkan secara Praktis yaitu sebagai wujud fisik sastra lisan yang lahir dan berkembang 
di dalam masyarakat Kurungan Nyawa dan upaya pencegahan punahnya Pisa'an serta mengiatkan tergeraknya lahirlah penelitian tentang sastra Komering, sebagai bentuk apresiasi tertinggi terhadap sastra lisan pisa'an Komering dan ikut membantu dalam upaya pendokumentasian sastra lisan dari segi ilmu pengetahuan dan sebagai pendukung terwujudnya visi misi prodi tentang upaya pelestarian kearifan budaya lokal melalui penelitian terhadap sastra lisan Komering sebagai kebudayaan masyarakat pribumi.

\section{METODE/EKSPERIMEN}

Jenis penelitian yang digunakan dalam penelitian ini adalah penelitian kualitatif karena digunakan untuk memperoleh data untuk memberikan gambaran objek berdasarkan masalah yang diangkat yaitu Pisaa'an pada pemberian adok pernikahan adat Komering. Metode yang digunakan dalam penelitian ini adalah metode deskriptif analitatif karena penulis ingin mengungkapkan, menggambarkan, dan memaparkan struktur dan makna Pisa'an dalam sesuai dengan data yang didapatkan peneliti dilapangan. Pendekatan penelitian ini adalah pendekatan struktural, karena peneliti akan menganalisis keseluruhan teks yang ditujukan untuk mengetahui keterkaitan antarunsur dan aspek-aspek dalam karya sastra. Data dalam penelitian ini adalah teks Pisa'an Komering pemberian adok penikahan. Sumber data dalam penelitian ini adalah pelaku dan penyair Pisa'an pemberian Adok pernikahan, catatan atau teks tertulis Pisa'an yang disenandungkan ketika upacara adat pernikahan yang telah diterjemahkan ke dalam bahasa Indonesia. Teknik pengumpulan data mengunakan metode observasi, wawancara, dan perekaman. Dan terakhir teknik analisis data yaitu dengan mengikuti prosedur teori structural Ade dkk menganalisis sebuah karya sastra.

\section{HASIL DAN PEMBAHASAN}

Data dalam penelitian ini adalah teks Pisa'an pemberian adok penikahan pada pernikahan adat Komering yang berlangsung di desa Kurungan Nyawa. Ada tiga Pisa'an pemberian Adok dalam pernikahan adat Komering yang menjadi data yang akan dianalisis. Data pertama adalah Pisa'an pemberian Adok pada pernikahan Teddy Hengky Wibowo dan Vina Pilipesense yang dituliskan oleh Ernawati, berdasarkan hasil musyawarah keluarga pengantin laki-laki. Data ini diperoleh melalui proses perekaman dan pengamatan secara langsung ketika Pisa'an disenandungkan oleh penyair bernama Abu Usman Jahri, sesaat setelah proses ijab kabul dilangsungkan. Pernikahan ini dilaksanakan pada tanggal 13 juni 2019, bertempat di kediaman pengantin laki-laki.

Data kedua adalah Pisa'an pemberian Adok pada pernikahan Redi Wihandra dan Liawati yang dituliskan oleh Ernawati, berdasarkan hasil musyawarah keluarga pengantin laki-laki. Data ini diperoleh melalui proses perekaman dan pengamatan secara langsung ketika Pisa'an disenandungkan oleh penyair bernama Abu Usman Jahri, keesokan hari pada saat acara resepsi pernikahan. Pisa'an disenandungkan pada tanggal 9 februari 2019 bertempat di kediaman pengantin laki-laki. Sedangkan data ketiga adalah Pisa'an pemberian Adok pada pernikahan Rino Kurniawan dan Sanda Pelangi yang dituliskan oleh Bustan, berdasarkan hasil musyawarah keluarga pengantin laki-laki. Data ketiga ini diperoleh melalui proses perekaman dan pengamatan langsung ketika pisa'an disenandungkan oleh penyair bernama Cek Nilam, sesaat setelah proses ijab kabul dilangsungkan. Pernikahan ini dilaksanakan pada tanggal 09 januari 2019, bertempat di kediaman pengantin perempuan. Ketiga Pisa'an ini berupa bunyi belum berupa tulisan. Sehingga untuk memperkuat data tersebut peneliti melakukan transkripsi data dari bunyi menjadi tulisan.

\section{Pembahasan}

Penelitian yang telah dilakukan dan melakukan analisis terhadap tiga Pisa'an yaitu Pisa'an pemberian adok pada pernikahan Teddy Hengky Wibowo dan Vina Pilipesense dan Pisa'an 
pemberian adok pada pernikahan Redi Wihandra dan Liawati, serta Pisa'an pemberian Adok pada pernikahan Rino Kurniawan dan Sanda Runnih yang semua datanya diperoleh di desa Kurungan Nyawa, maka dari ketiga Pisa'an ditemukan bahwa Pisa'an pemberian Adok pernikahan adat Komering mengandung pengalaman, petuah, nasehat, serta cerminan kebudayaan suku Komering yang kuat. Setiap Pisa'an yang tercipta oleh masyarakat Komering dijadikan sebagai pedoman hidup, sarana menyampaikan pendapat, perasaan dan kritik sosial. Hal ini sangat terlihat jelas dari tiap unsur dari struktur Fisik maupun struktur batin.

Hakikat dari proses pengkajian atau analisis sebuah pisa'an adalah mengetahui makna secara utuh dan padu yang tersembunyi di dalamnya. Makna inilah yang menjadi pengikat kuat dan tidak dapat dipisahkan antara unsur fisik (diksi, imaji, kata konkret, majas, verifikasi dan tifografi) dan unsur batin (tema, nada dan suasana, perasaan, serta amanat) dari sebuah Pisa'an. Hubungan makna antara satu unsur dengan unsur lain, bisa saja pada hubungan antara sesama unsur fisik, sesama unsur batin atau berlawanan yaitu unsur fisik dan batin. Ini tergantung kaitan makna unsur mana yang paling mendominasi yang ingin ditunjukkan oleh penyair agar tersampaikan maksud dan tujuannya dalam sebuah Pisa'an.

Penelitian yang telah dilakukan dan melakukan analisis terhadap tiga Pisa'an yaitu Pisa'an pemberian adok pada pernikahan Teddy Hengky Wibowo dan Vina Pilipesense dan Pisa'an pemberian adok pada pernikahan Redi Wihandra dan Liawati, serta Pisa'an pemberian Adok pada pernikahan Rino Kurniawan dan Sanda Runnih yang semua datanya diperoleh di desa Kurungan Nyawa, maka dari ketiga Pisa'an ditemukan bahwa Pisa'an pemberian Adok pernikahan adat Komering mengandung pengalaman, petuah, nasehat, serta cerminan kebudayaan suku Komering yang kuat. Setiap Pisa'an yang tercipta oleh masyarakat Komering dijadikan sebagai pedoman hidup, sarana menyampaikan pendapat, perasaan dan kritik sosial. Hal ini sangat terlihat jelas dari tiap unsur dari struktur Fisik maupun struktur batin.

Hakikat dari proses pengkajian atau analisis sebuah pisa'an adalah mengetahui makna secara utuh dan padu yang tersembunyi di dalamnya. Makna inilah yang menjadi pengikat kuat dan tidak dapat dipisahkan antara unsur fisik (diksi, imaji, kata konkret, majas, verifikasi dan tifografi) dan unsur batin (tema, nada dan suasana, perasaan, serta amanat) dari sebuah Pisa'an. Hubungan makna antara satu unsur dengan unsur lain, bisa saja pada hubungan antara sesama unsur fisik, sesama unsur batin atau berlawanan yaitu unsur fisik dan batin. Ini tergantung kaitan makna unsur mana yang paling mendominasi yang ingin ditunjukkan oleh penyair agar tersampaikan maksud dan tujuannya dalam sebuah Pisa'an.

\section{Bantang Adok sabai pun (pengumuman gelar pada besan laki-laki) \\ Bantang muloh sada pun (pengumuman gelar bersahut pada besan peremuan)}

Kalimat di atas dipastikan ada pada setiap Pisa'an pemberian Adok pernikahan, dan ini menjadi ciri khas pembeda antara Pisa'an pernikahan dan Pisa'an lainya sekaligus penanda pengumuman gelar untuk pengantin, jika ditujukan pada sabai atau besan laki-laki maka secara otomatis gelaran atau Adok tersebut ditujukan untuk pengantin laki-laki. Pun sebaliknya jika ditujukan pada sada atau besan perempuan maka secara otomatis gelaran atau Adok tersebut ditujukan untuk pengantin perempuan.

Setiap unsur mewakili setiap cerita tentang kedua pengantin yang diberikan Adok baik itu tentang kisah cintanya, tentang latar belakang keluarganya, dan petuah-petuah untuk menjalani kehidupan berumah tangga. Hal inilah yang menjadikan Pisa'an unik, sarat makna, dan berbeda dengan pantun pada umumnya. Selain memiliki ciri khas tifografinya yang unik, temanya yang seragam (tentang pernikahan), Pisa'an kaya akan kebudayaan Komering karena kehidupan kedua pengantin diceritakan secara mendetail, menyeluruh dan mendalam. 
Penggalan Pisa'an pertama

Bantang Adok sabai pun

\author{
Alang puas keliling \\ Tigoh de pulau Jawa \\ Barong mangsa pudamping \\ Adok Batin Surya Mustika
}

Terjemahan penggalan Pisa'an yang pertama

Pengumuman gelar pada besan laki-laki

\title{
Sangat puas berpetualang \\ Hingga sampai di pulau Jawa \\ Begitu dipertemukan dengan pendamping \\ Gelarnya Batin Surya Mustika
}

Makna yang terkandung dalam Pisa'an pertama yaitu Pisa'an pemberian Adok pada pernikahan Teddy Hengky Wibowo dan Vina Pilipesense di atas dalah proses terjadinya pernikahan yaitu dimulai seorang Teddy Hengky Wibowo melakukan proses pencarian, berpetualangan, meninggalkan tanah kelahiran sampai ke pulau Jawa dengan usaha maksimal untuk menemukan jodohnya. Hingga Teddy Hengky Wibowo ini dipertemukan dengan Vina Pilipesense yang merupakan sosok wanita idamannya.

Penggalan Pisa'an kedua

\section{Bantang Adok sabai pun}

\section{Luahan jak Karang}

Camat Buay Bahuga

Adok Batin Penyimbang

Kok terang de uyin merga

Terjemahan penggalan Pisa'an yang kedua

\section{Pengumuman gelar pada besan laki-laki}

\section{Keluaran dari Karang \\ Camat Buay Bahuga \\ Gelarnya Batin penyimbang \\ Sudah jelas disemua marga}

Makna yang terkandung dalam Pisa'an kedua yaitu Makna yang terdapat dalam Pisa'an pemberian Adok pada pernikahan Redi Wihandra dan Liawati adalah Jika sudah ditakdirkan berjodoh, walaupun mempunyai asal yang berbeda, maka akan dipertemukan disuatu tempat yang sama.

Penggalan Pisa'an ketiga

\section{Bantang Adok sada sabai pun}




\title{
Bismillah pangkal cawa \\ Betangguh de seramik dija \\ Bakal ngadokkon tiyan rua \\ Ram Komering cuncun jama
}

Terjemahan penggalan Pisa'an yang kedua

\section{Pengumuman gelar pada kedua besan}

\author{
Bismillah pembuka kata \\ Permisi seluruh hadirin yang ada \\ Untuk memberi gelar pengantin berdua \\ Kita Komering junjung bersama
}

Makna yang terkandung dalam Pisa'an ketiga yaitu Pisa'an pemberian Adok pada pernikahan Rino Kurniawan dan Sanda Runnih adalah keyakinan terhadap firman Allah SWT dalam Al-Quran bahwa laki-laki baik untuk perempuan baik dan pernikahan adalah awal dari kehidupan yang baru serta nasehat untuk terus melestarikan kebudayaan Komering yang luhur.

Struktur fisik dari ketiga Pisa'an pada dasarnya sangat mirip. Diksi dari ketiga Pisa'an dalam pemberian Adok pernikahan adat Komering mempunyai beberapa pemilihan diksi yang sama seperti kata bantang, adok, sada, dan sabai. Imaji ketiga Pisa'an ini, umumnya lebih dominan imaji taktil dibandingkan imaji audio dan visual. Hal ini karena di dalam Pisa'an tersebut penyair lebih banyak bermain rasa untuk membimbing siapa saja yang mendengar senandung Pisa'an merasakan apa yang telah dialami oleh kedua pengantin hingga pernikahan terjadi dan ikut memanjatkan doa untuk kedua pengantin.

Kata konkret pada tiga Pisa'an dalam pemberian Adok pernikahan adat Komering ini, sangat berbeda tetapi sama-sama mengacu pada pengkonkretan asal usul pernikahan itu terjadi, misalnya pada Pisa'an pertama mengunakan kata pulau Jawa yang merujuk tempat pertualangan si lelaki mencari pendamping hidup. Karangan dalam Pisa'an kedua merujuk asal muasal kelahiran pengantin laki-laki. Begitu pun dengan Pisa'an ketiga kata Komering memperjelas sekali bahwa kedua pengantin adalah suku Komering dan mengunakan adat Komering dalam konsep pernikahannya.

Majas yang digunakan dalam ketiga Pisa'an ini banyak mengunakan majas personifikasi, sinekdoke part prototo dan hiperbola. Sedangkan verifikasi dari ketiga Pisa'an ini juga hampir sama. Rima yang mendominasi tiga Pisa'an ini yaitu, rima berselang, rima depan, rima akhir, aliterasi dan efoni. Begitupun ritma dalam ketiga Pisa'an ini didominasi ritma andante dan ritma allegro. Sedangkan untuk metrum sama sama berpola statis. Verifikasi yang hampir sama ini diakibatkan oleh nada kebahagian yang diciptakan penyair dalam ketiga Pisa'an. Dan struktur fisik Pisa'an yang terakhir adalah tifografi.

Tifografi Pisa'an umumnya sama dengan pantun, tetapi tifografi Pisa'an pemberian adok pernikahan adat Komering sangat berciri khas, yaitu baris yang berdiri sendiri yang letaknya ada setiap sebelum bait Pisa'an. Baris-baris yang berdiri sendiri itu dimaksudkan sebagai pertanda untuk siapa bait-bait setelahnya diperuntukan, dengan ditandai pengunaan kata sada dan sabai. Sabai untuk pengantin laki-laki dan sada untuk pengantin perempuan. Hal ini dapat dipastikan selalu ada pada setiap Pisa'an pemberian Adok pernikahan, yang membedakan pisa'an yang satu dan yang lain hanyalah jumlah bait-bait Pisa'an yang dibuat penyair. Seperti yang terlihat dalam bentuk utuh Pisa'an ketiga, yaitu:

\section{Bantang Adok sada sabai pun}

Bismillah pangkal cawa Betangguh de seramik dija

Neti Kartini, Suryani 
Bakal ngadokkon tiyan rua Ram Komering cuncun jama

\title{
Bantang Adok sabai pun
}

Raja Sekawan sa bani

Mejong de unggak pusiban

Lapah mena da kuti

Ya lapah selinggahan

\section{Bantang Adok muloh pun}

\author{
Gagah sua berani \\ Sanggon pakaian raja \\ Ya nalom betik hati \\ Rakyat aman segala
}

\section{Bantang Adok sada pun}

\author{
Ratu Takunan nari \\ Pakai kamban sutera \\ Ya nalom betik hati \\ Surah budi bahasa
}

\section{Bantang adok muloh pun}

Alif huruf Al-Quran

Pasal mula de bimbingan

Hukum kok te canangkon

Mula kukuh keyakinan

\section{Bantang Adok sada sabai pun}

Gusti puhgun jama denggi

Sija bakal jadi gaman tiyan

Raja ratu jadi tradisi

Bebiduk sai delom kehurikan

Setelah menganalisis struktur fisik ketiga Pisa'an tersebut maka struktur batin ketiga Pisa'an sudah sangat terlihat jelas. Tema pada setiap Pisa'an pemberian Adok semuanya bertema tentang pernikahan. Pembeda antara tema Pisa'an satu dengan yang lainnya adalah latar belakang kehidupan, keluarga, silsilah, hingga sikap dan prilaku kedua pengantin yang diberikan Adok. Pisa'an pertama lebih menekankan pada pertualangan seorang laki-laki dalam mencari cinta sejatinya, dan Pisa'an kedua menekankan pada bahwa tempat bukan perkara jika memang takdir untuk berjodoh, sedangkan Pisaa'an ketiga menekankan silsilah dan latar belakang keluarga berpengaruh besar dalam membentuk kepribadian dan masa depan seseorang ketika nantinya berumah tangga.

Perasaan yang diungkap penyair dalam ketiga Pisa'an menekankan pada rasa perjuangan kedua pengantin hingga akhirnya mereka dipersatukan di dalam ikatan pernikahan dan rasa kebahagian kedua belah pihak keluarga. Nada yang disampaikan penyair adalah nada kebahagian yang sangat terlihat jelas dari rima eufoni yang mendominasi ketiga Pisa'an, sedangkan suasana yang diakibatkan nada adalah suasana yang sangat terasa, ceria dan menginspirasi. Terakhir adalah amanat. Amanat yang disampaikan oleh penyair sangat banyak sekali terutama tentang nasehat pernikahan, jodoh, dan keluarga dalam peradaban masyarakat suku Komering yang sangat menjunjung tinggi pernikahan satu kali seumur hidup.

\section{PENUTUP}

Berdasarkan hasil penelitian dan analisis terhadap tiga Pisa'an yaitu Pisa'an pemberian adok 
pada pernikahan Teddy Hengky Wibowo dan Vina Pilipesense dan Pisa'an pemberian adok pada pernikahan Redi Wihandra dan Liawati, serta Pisa'an pemberian Adok pada pernikahan Rino Kurniawan dan Sanda Runnih yang semua datanya diperoleh di desa Kurungan Nyawa, maka dari ketiga Pisa'an tersebut dapat disimpulkan bahwa Pisa'an pemberian Adok pernikahan adat Komering mengandung pengalaman, petuah, nasehat, serta cerminan kebudayaan suku Komering yang kuat. Setiap detail kata dalam Pisa'an yang tercipta oleh masyarakat Komering dijadikan sebagai pedoman hidup, sarana menyampaikan pendapat, perasaan dan kritik sosial. Hal ini sangat terlihat jelas dari tiap unsur dari struktur fisik maupun struktur batin.

Berdasarkan pada penelitian yang telah dilakukan, maka saran-saran yang dapat diberikan peneliti yang pertama bagi prodi Pendidikan Bahasa dan Sastra Indonesia diharapkan dapat memberikan perhatian lebih terhadap sastra-sastra Komering untuk dijadikan objek penelitianpenelitian lanjutan untuk mencegah kepunahan terutama sastra lisan. Kedua bagi mahasiswa yang akan melakukan penelitian guna penulisan skripsi bisa meneliti lebih mendalam mengenai verifikasi Pisa'an dari bidang fonologi, mengkaji tentang sastra Komering mengunakan sudut pandang penyair atau analisis strukturalisme genetik, dan pengkajian tentang pembelajaran sastra Komering di OKU Timur yang masih sangat minim di dalam dunia pendidikan. Dan ketiga bagi suku Komering, sadarilah bahwa sesungguhnya kalian adalah suku pribumi yang sangat kaya akan sastra terutama lisan. Dan jika hingga saat ini belum menyadarinya maka ini adalah kerugian yang sangat nyata. Tunjukkanlah kecintaan kalian dengan cara apapun yang kalian bisa, seperti melanjutkan penelitian sastra Komering Pisa'an ini, atau belajar Pisa'an langsung dari penyair di daerah tempat tinggal kalian.

\section{DAFTAR PUSTAKA}

Aminudin, 2009. Pengantar Apresiasi Karya Sastra. Bandung: Sinar Baru Algesindo.

Badan Pusat Statistik Jakarta Pusat. 2016. Statistik Indonesia Tahun 2016. Jakarta Pusat : Badan Pusat Statistik

Didipu, Herman. 2012. Sastra Daerah: Konsep Dasar dan Ancangan Penelitiannya. Jakarta: Dapur Buku.

Depdikbud. 2013. Kamus Bahasa Komering. Palembang . Balai Pustaka.

Hikmat, Ade, Nur Aini Puspitasari dan Syarif Hidayatullah. 2017. Kajian Puisi. Jakarta: UHAMKA

Hutomo, Suripan Sadi. 1991. Mutiara yang terlupakan: Pengantar Stusi Sastra Lisan. Surabaya : HISKI Jawa Timur

Moleong, Lexi J. 2017. Metodologi Penelitian Kualitatif. Edisi Revisi. Bandung: Remaja Rosdakarya.

Pradopo, Rachmat Djoko. 1990. Pengkajian Puisi. Yogyakarta: Gadjah Mada University Press.

Rokhmansyah, Alfian. 2014. Studi Dan Pengkajian Sastra. Yogyakarta: Graha Ilmu.

Sangidu, Herman. 2004. Metode Penelitian Satra, Pendekatan Teori, Metode dan Kiat. Yogyakarta: UGM

Sugiyono. 2011. Metode penelitian Pendidikan (Pendekatan Kuantitatif, kualitatif, dan R\&D). Bandung: Alfabeta.

Teeuw, Andries.2013. Sastra dan IImu Sastra: Pengantar Teori Sastra. Jakarta: Pustaka Jaya.

Waluyo, J. Herman. 1991. Teori dan Apresiasi Puisi. Jakarta: Erlangga.

2002. Apresiasi Puisi Jakarta: Gramedia Pustaka Utama.

Neti Kartini, Suryani 